\title{
A Historiographical Survey of Literacy in Britain between 1780 and 1830
}

Devon Lemire

\begin{abstract}
This paper examines the historiography of literacy between 1780 and 1830 in Britain. The paper first explores the challenges faced by historians in measuring literacy and examines the lenses through which historians have interpreted the available data. Factors thought to contribute to rising literacy rates in this time period include access to education, the Industrial Revolution, religious movements and gender norms.
\end{abstract}

\section{Introduction}

Literacy, especially in early modern and Victorian Britain, has been fairly extensively studied by a number of historians using a variety of approaches. The central question in this type of study revolves around what exactly literacy meant at the time and how it can be measured accurately and effectively. It is generally agreed that literacy levels rose fairly dramatically in the late eighteenth and early nineteenth centuries, though historians disagree about why this occurred and what caused this trend. Edmund Burke, a contemporary, estimated that in 1790 there were approximately 80000 people who could be considered part of the English reading public. ${ }^{1}$

Historians have for the most part employed three broad approaches to examine literacy and the questions surrounding it. Some historians have used quantitative methodologies to attempt to measure literacy levels by looking at documents like marriage registers where both the bride and groom signed their names or made a mark indicating a legal marriage. The varying definitions of literacy and the types of evidence available has resulted in a range of estimates regarding the overall literacy rates in Britain.

Other historians have examined literacy using the Marxist theory of class structure within the context of the Industrial Revolution. Historians have examined common occupations during the period and prevalent social conditions to determine whether these had any effect on literacy rates. Opinion is divided over the basic question of whether the Industrial Revolution encouraged reading and writing or whether it actually devalued literacy for the common worker.

Finally, other historians examine literacy trends by looking at the social and cultural contexts of the period. The spread of accessible education and the role of Protestantism and religion have been studied in-depth. Again, historians are divided on the question of whether increased access to education contributed to increased literacy. Another divide surrounds the question whether religion encouraged ordinary people to value literacy and pursue primary education for themselves and their

\footnotetext{
1 Richard D. Altick, The English Common Reader: A Social History of the Mass Reading Public 1800-1900 (Chicago: The University of Chicago Press, 1957), 49.
} 
children. There has been significant work done on the relationship between gender and literacy. All of these different lenses must be examined to arrive at a historically appropriate answer.

Most of the research on literacy rates appears to have been done in a thirty-year period roughly between 1960 and 1990. Seemingly reflecting the popular trends in historical theory from this period, including Marxist interpretations, quantitative methodologies and the beginnings of gender history. Literacy has, for the most part, been thoroughly examined though these interpretative lenses, but there has been next to nothing done on the topic after 1990. The likely cause of the recent halt in research is the rise of postmodernist interpretations. However, there remain unanswered questions about the beginnings of Britain's movement towards mass literacy.

\section{Measuring Literacy}

The fundamental debate in the study of literacy - for any time or place - is how to measure literacy levels appropriately and effectively. It is hard to define exactly what characteristics need to be present to define a person as literate. Are people considered literate if they can read but not write? Is numeracy an inherent part of literacy or a completely different issue? Does signing one's name in a marriage register count as proof of literacy? These basic questions have been debated by many historians who have studied literacy each of whom has outlined his or her benchmark definition through the study the quantitative rates, contributing factors, or the social implications of literacy. The first national report on literacy in 1840 , based on marriage registers, estimated that $67 \%$ of males and $51 \%$ of females were literate. ${ }^{2}$ This report is the most commonly used indicator of literacy, especially after 1754, when a standardized marriage certificate was introduced. ${ }^{3}$ One of the most common problems is defining what literacy actually means. David Mitch pointed out we normally think of literacy as demonstrating proficiency in both reading and writing, but in the eighteenth and nineteenth centuries this was often not the case. Some people only mastered reading or writing, while the two were often taught separately and partial literacy was fairly common. ${ }^{4}$ It's possible that about twice as many people could read as write in early Victorian England, a very real problem for historians trying to set a benchmark for literacy.

Lawrence Stone is one of the earliest historians to have written about literacy in Britain. He estimated male literacy rose six or seven percent to $56 \%$ between 1700 and $1775 .{ }^{5}$ In his research Stone acknowledged the extreme difficulty of measuring literacy accurately and the discrepancy between the ability to sign one's name and actually being literate. For his quantitative study of literacy over three centuries in Britain, he used the ability to sign a marriage register as a benchmark, but recognized it is not ideal. ${ }^{6}$ His chief concern with the use marriage registers to measure literacy is someone with the ability to sign his or her name would not necessarily have the ability to communicate effectively using the written word. He referred to this phenomenon as "alphebetism" instead of true literacy. ${ }^{7} \mathrm{He}$ also stated reading and writing were taught separately, so a person who knew how to read could not necessarily write. ${ }^{8}$ Stone admitted marriage registers were somewhat

\footnotetext{
2 Altick, The English Common Reader, 170.

3 Michael Sanderson, Education, Economic Change and Society in England 1780-187, 2nd ed. (Cambridge: Cambridge University Press, 1995) 2.

${ }^{4}$ David F. Mitch, The Rise of Popular Literacy in Victorian England: The Influence of Private Choice and Public Policy (Philadelphia: University of Pennsylvania Press, 1992) xvii.

${ }^{5}$ Sanderson, Education, Economic Change and Society in England 1780-1870, 3.

${ }^{6}$ Lawrence Stone, "Literacy and Education in England 1640-1900," Past and Present 42 (1969): 98.

7 Ibid.

${ }^{8}$ Ibid.
} 
shaky evidence of literacy rates, because the average ages for finishing school and getting married were several years apart, enough time to forget learned skills.'

Richard Altick, another early historian of literacy, examined this problem in a slightly different light. He pointed out marriage registers were used for census purposes, but few people used their literacy skills after finishing school, and thus may not have been as literate as they were when they finished their education. ${ }^{10}$ When literacy skills were tested in schools, students were only required to read some portions of the Scripture or the Catechism and were not tested on their understanding. ${ }^{11}$ Altick points out even contemporary surveys of literacy were flawed because of the criteria used to measure literacy. Passing an exam in school may have counted as literacy for the government, but may not be a good indicator of whether a person was functionally literate. His claim was illiteracy was far more widespread than even officials of the time thought. ${ }^{12}$

Roger Schofield has investigated different ways of measuring literacy. He noted there are two principal methods used to investigate literacy rates. These are indirect methods of measurement such as school graduates and the volume of publications - and the more direct method represented by marriage register signatures. ${ }^{13}$ Indirect methods of measurement are inexact because of the large numbers of variables involved. ${ }^{14}$ The number of publications, while likely related to literacy rates, does not have a simple cause and effect relationship with literacy. For example, an increase in publications may have been related to better printing technologies, rather than increased demand. Thus, it is difficult to determine how much of an effect literacy rates had upon publication rates. Unfortunately, the direct measures, such as marriage registers, are not completely reliable either, for the simple reason there is no uniform definition of standards of literacy. ${ }^{15}$ Therefore, marriage registers do not provide the most conclusive evidence, but there are few alternatives that measure literacy as easily.

Michael Sanderson agreed marriage registers are by far the most comprehensive and widespread evidence about literacy available. Conversely, his belief was they are a better measure of illiteracy than literacy. ${ }^{16}$ Sanderson suggested that historians could definitively know which people could not write or read because they would have been forced to make a mark in the marriage register. ${ }^{17}$ As we know, the presence of a signature tells us very little because it is unable to demonstrate the extent of a person's reading and writing skills. This is the basic limitation of marriage registers from Britain historians must work with. Sanderson stated that Stone's original estimates were too optimistic. Conversely, he has suggested there was a large rise in population between 1760 and 1830, which likely strained the school system and drew children into the industrialization process. ${ }^{18}$ Thus, we must be careful to examine the differences in literacy trends between the industrial towns where literacy likely declined and the rural communities where literacy rates were probably beginning to rise. ${ }^{19}$ In fact, Sanderson warned historians the overall picture of literacy is not nearly as uniform as some think, and this must be taken into account to produce an accurate picture.

\footnotetext{
${ }^{9}$ Ibid.

10 Altick, The English Common Reader, 169.

11 Altick, The English Common Reader, 169.

12 Ibid, 170.

13 R. S. Schofield, “Dimensions of Illiteracy 1750-1850," Explorations in Economic History 10, no. 4 (1973): 3.

14 Ibid.

15 Ibid.

16 Sanderson, Education, Economic Change and Society in England 1780-1870, 2.

17 Ibid.

18 Ibid, 4-5.

${ }^{19}$ Ibid, 7.
} 
W. B. Stephens also agreed marriage registers were the most comprehensive measurement of literacy. However, he too warned that historians needed to be more careful about their numbers. The biggest reason for this warning was literacy rates could vary quite widely between town, country, different types of urban areas, and between counties. ${ }^{20}$ This difference in literacy meant using the nation-wide numbers obtained from marriage registers obscures crucial differences between diverse segments of the population, which need to be explained more thoroughly. The generalizations made from this nation-wide data meant the population appeared to be homogeneous, even though there was a wide variety of economic, social, and in some cases, cultural differences throughout England. Different groups may have had different reasons for valuing reading and writing, or different access to education. ${ }^{21}$ For example, a rural farmer whose community rarely had access to books likely would have valued reading less than someone living in an urban setting where books were more commonplace. The other thing historians have failed to take into account is the problem of migration and how this affected literacy rates in both children and adults. ${ }^{22}$ Children would have been less likely to attend school on a regular basis and adults would have had little opportunity to learn when constantly on the move looking for employment. The social situation of early modern England was not have been conducive to learning.

David Vincent felt a more interdisciplinary approach should have been used to measure literacy. He agreed that marriage registers were useful because of the standardized measurement and reasonably firm numbers they provided. However, he suggested more qualitative data should be used in conjunction with the numbers derived from marriage registers. ${ }^{23}$ Marriage registers can provide a basic understanding of literacy rates, but have little social context. For example: do we know that all people who made marks were actually illiterate, or did they get nervous? Did people misrepresent their literacy on marriage registers for any reason? Was the status of being able to sign one's name enough that people would make a special effort to learn before their marriage ${ }^{24}$ Was there any evidence that people made marks instead of signing because they did not want to look like upstarts? Vincent suggested that qualitative evidence about social conditions and the prevailing attitudes towards literacy could help us to understand the context of a signature in a marriage register. ${ }^{25}$

\section{Literacy and Education}

One of the main things historians have to focus on when studying literacy is the role of education. It seems probable the increased education for the poor and working classes in Britain in the late eighteenth and early nineteenth centuries was an important factor contributing to the rise of literacy. The upper classes, of course, were able to send their sons to public schools and universities, which had become fairly restrictive. ${ }^{26}$ Conversely, the lower classes, who usually couldn't afford the public schools, sent their children to charity schools or slightly higher class schools that had been endowed. Religious organizations or secular philanthropists who supported elementary education for the masses generally ran these schools. ${ }^{27}$ Schools were the place where children generally learned to read and write and those who didn't attend some sort of school were likely to remain illiterate. However, historians argue about how effective education was. Some take the position that education

\footnotetext{
${ }^{20}$ W.B. Stephens, ed. Studies in the History of Literacy: England and North America (Leeds: Museum of the History of Education, University of Leeds, 1983.) 3.

21 Stephens, Studies in the History of Literacy, 3.

22 Ibid, 4.

${ }^{23}$ David Vincent, Literacy and Popular Culture: England 1750-1914 (Cambridge: Cambridge University Press, 1989$) 17$.

${ }^{24}$ Ibid, 31.

25 David Vincent, Literacy and Popular Culture: England 1750-1914, 18.

26 Altick, The English Common Reader, 31

${ }^{27}$ Mitch, The Rise of Popular Literacy in Victorian England, xiv.
} 
was ineffective for a variety of reasons. These reasons include the limited amount of time most children spent in school and the irregularity of their education. Others discuss how children may have been taught reading, writing and arithmetic, but because they never used these skills beyond the three years or so they attended school, they ended up losing literacy later in life. Finally, other historians believe the pedagogy of the schooling systems was not particularly useful in teaching children how to read, but rather taught them good memorization skills. The students were tested on their ability to read parts of the Bible, but some historians have argued this did not test what they had learned, because there was such an emphasis on memorizing important passages and works. Education was fundamental to teaching people how to read and write, but historians are unsure of how effective the teaching methods were at giving people the tools to become literate. This uncertainly begs the question why there was an increase in literacy between 1770 and 1830 . If people were not gaining much in terms of literary skills from the average charity school, does that mean people were teaching themselves how to read and write? Was there something that made literacy more valued than it had been in the past, which made people take the initiative?

Richard Altick argued the standards for teachers at the time were extremely low. Teachers were often barely literate themselves and were unable to pass on literacy skills very well, especially charity school instructors. ${ }^{28}$ These teachers were not held in high regard for the most part and often the dregs of society worked to teach children how to read and write. However, this was not always the case - some positions paid better than others - but for the most part, teachers in the charity schools were not particularly good. ${ }^{29}$ Better schools tended to have private endowments and were able to provide a higher level of education than charity schools. The endowed schools sometimes charged a small weekly fee, but were less concerned with teaching children to keep their places. On the other hand, the charity schools saw education as a more of a governmental duty rather than a right. The schools in the nineteenth century were not very enjoyable for children either and for many reading and writing were deemed unimportant and so were not inclined to pursue literacy further than necessary. ${ }^{30}$

Mitch has argued the demand for reading and writing skills within the working class was independent of the educational policies of the time. ${ }^{31}$ He believed the interaction between public and private policies was what shaped the demand for education, though this became more noticeable later in the Victorian period. Mitch employed a cost-benefit approach to determine its impact on literacy rates. ${ }^{32}$ The Victorian approach was to introduce legislation at the national level. The way individuals reacted to and interacted with these national policies determined the impact they had on society. Mitch argued that popular attitudes towards education influenced public policy, as well as the effectiveness of public education. This was especially true as more democratic control of educational policy was put in place.

E. G. West looked at education in nineteenth century in Britain from an economic perspective. He criticized historians for reading too deeply into the legislation of public education, and subsequently the effect of education. ${ }^{33}$ He reminded his readers that teaching and learning had been present for a long time and it was not a new phenomenon in the eighteenth and nineteenth century. He noted

\footnotetext{
28 Altick, The English Common Reader, 34.

${ }^{29}$ Ibid.

30 Altick, The English Common Reader, 150.

31 Mitch, The Rise of Popular Literacy in Victorian England, xiv.

32 Ibid, xx.

33 E.G. West, "Resource Allocation and Growth in Early Nineteenth-Century British Education," Economic History Review 23, no. 1 (1970): 72.
} 
that between 1800 and 1840, there was a fairly dramatic increase in the supply and demand of education. In 1833 the government began providing subsidies for education. ${ }^{34}$ However, he closely analyzed the economics of education to determine how many people were able to make use of them. Even though charity schools were beginning to be subsidized, the families of the children attending were required to pay most fees. ${ }^{35}$ By multiplying the number of children whose families paid fees for them by the number of children attending school, West attempted to work out how many children received "free" schooling. He concludes that the average weekly cost of attending school was $9 d$ per week. $^{36}$ Another aspect taken into account by West was how many days a year a child attended school. There were increased numbers of holidays and many students only attended school part time, especially during the harvest when they were needed at home. ${ }^{37}$ He summarized that much of the quantitative evidence we have suggests people were interested in education, but the prohibitive costs prevented all but those of the wealthy upper classes from going regularly. ${ }^{38}$ This meant the parents of working class children often had chose between educating their child and using them as an extra source of income. West believed this was a reason education and literacy rates did not greatly increase until the later nineteenth century.

David Vincent has made an interesting point about equating literacy and education. People have tended to equate literacy as a product of increased educational opportunities, because these institutions were where reading and writing were taught. However, Vincent has pointed out that during the eighteenth and nineteenth centuries, and indeed up until modern times, literacy has been used as an indicator of the success of the education system. ${ }^{39}$ This assumed connection has been especially true for schools receiving public funds required to prove fiscal accountability. Therefore, it is conceivable that schools trying to increase their funding may have focused intensely on preparing children for specific exams, rather than teaching them to understand what they read and wrote. A child might be asked to read a passage or to write a paragraph, but these would have been memorized beforehand. The child might read or write a passage perfectly, but have no understanding of it meant. As well, for many families, education was not a priority. Children had other skills to learn that would serve them better in their chosen occupations. ${ }^{40}$ Vincent suggested that for many, informal education was of more importance and use than formal schooling. Especially later in the nineteenth century, the prevalent attitude within the upper classes was working-class children should not be left to the ignorance of their parents. ${ }^{41}$ Interestingly, this sentiment is in direct opposition to the traditional belief the poor did not need or deserve education. These two distinct beliefs about education seem to have been competing at the time, though it is unclear how much they affected actual school attendance. These beliefs illustrate that society was grappling with the meaning of education and who needed it. Jonathan Payne has taken a similar view to Vincent, noting that autodidactism may have been prominent, especially in the middle and upper classes. For many, being able to read was an exploration, a chance to learn about their interests and to "improve" themselves. ${ }^{42}$ Both Payne and Vincent suggested that because the elementary school curriculum was non-conducive to enjoyment of learning and reading, those who were interested ended up teaching themselves. Children did not have a choice of reading material and were

\footnotetext{
${ }^{34}$ E.G. West, "Resource Allocation and Growth in Early Nineteenth-Century British Education," 78.

35 Ibid, 84.

36 Ibid.

${ }^{37}$ Ibid, 86.

${ }^{38}$ Ibid, 89.

${ }^{39}$ Vincent, Literacy and Popular Culture, 53.

40 Ibid, 56.

41 Ibid, 73.

42 Jonathan Payne, "Review Essay: Literacy and the Working Class,” Labour History Review 67, no. 3 (2002): 370.
} 
encouraged to memorize their lessons. Thus, they may never have gained a true appreciation of reading, or if they did, preferred to choose their own, more enjoyable reading material.

Books were also quite expensive, which made reading for leisure a costly habit. This was especially true prior to the 1770 s, after the 1770 s cheap reprints of literary series became more widely available to the general public. ${ }^{43}$ Only the wealthiest members of society could afford to buy many books for themselves, while the ordinary working class person would have had to spend a one or two weeks worth of wages to buy a single book. ${ }^{44}$ The price discouraged many members of the lower classes, because they viewed reading as inaccessible. As such, someone who wanted to teach himself or herself would have had to save up a sizeable amount of money to afford materials.

\section{Literacy and the Industrial Revolution}

Another debate about literacy rates concerns the effect the Industrial Revolution. The period between about 1770 and 1830 was one of great social and economic change in Britain. There were many new job opportunities available and many people changed their lifestyles to adapt to new social and economic circumstances. The debate between historians about literacy in this context is quite polemical. Some historians, such as Michael Sanderson, have stated that the Industrial Revolution had an adverse effect on overall literacy trends. Others, such as Thomas Laqueur, believed it increased literacy rates. These scholars have examined trends in literacy through a Marxist or class-centered approach, and have focused mainly on the working classes in their studies. The Industrial Revolution had a major effect on the daily lives of the working class and literacy has become one of the ways of measuring this period's effects on the population at large.

Michael Sanderson argued literacy rates dropped off in 1790 s during the Industrial Revolution. ${ }^{45}$ Sanderson has suggested the main decrease in literacy occurred because children were required to work longer hours and spent considerably less time in school learning to read and write. ${ }^{46}$. Literacy fell by the wayside as a result of decreased educational hours. Their parents were also forced to work longer hours and for many sending their children to school was too expensive, both in terms of fees and in terms of lost hours of work. The parents were generally shifting from some sort of subsistence farming to a rigid factory job with pay that often failed make ends meet. The rise of the factory system as a widespread means of manufacturing goods meant there were more jobs that were best done or could only be done by school aged children. An example of these jobs is seen in textile factories where smaller hands were considered a benefit. ${ }^{47}$ Sanderson has also claimed that because of the migratory nature of many working class families during the Industrial Revolution, children were even less likely to attend school regularly or for an extended period of time. ${ }^{48}$ Access to education is the determining factor for literacy according to Sanderson, even though it is uncertain how much of an effect education has on literacy rates. Sanderson has admitted that the Industrial Revolution might not have precipitated such a decline in overall literacy rates if it hadn't been for other factors such as declining investment in primary education. ${ }^{49}$ In conclusion Sanderson stated that the Industrial Revolution actually produced a more illiterate society because of the rising population, new technologies that did not require reading or writing, and increased demand for child

\footnotetext{
43 Altick, The English Common Reader, 52

44 Ibid, 51.

${ }^{45}$ Michael Sanderson, "Literacy and Social Mobility in the Industrial Revolution in England," Past and Present 56 (1972):

78.

46 Ibid.

${ }^{47}$ Ibid, 79.

48 Ibid.

${ }^{49}$ Sanderson, Education, Economic Change and Society in England 1780-1870, 80.
} 
labourers. ${ }^{50}$ Literacy seems to have reached a low between 1810 and 1820 followed by a fairly steady rise, which has mainly attributed to increased education provided by both charity and Sunday schools. ${ }^{51}$

Thomas Laqueur directly countered Michael Sanderson's article by saying the Industrial Revolution had no part to play in the decline of literacy between 1790 and 1815. First of all, he argued with Michael Sanderson's dating of the decline stating that it must have started earlier than $1790 .^{52}$ Laqueur continued to attribute this decline to the use of marriage registers, noting that most of the population would have gotten married ten to fifteen years after completing their primary education. Thus, the decline in levels of literacy must have started ten to fifteen years before Michael Sanderson's estimate of 1790 , though it would not have been widely measured before those children reached a marriageable age. ${ }^{53}$ Laqueur also refuted Sanderson's explanation of the factory system as a reason for the decline in literacy stating the factory system did not come into effect in Lancashire until 1774 - fifteen to twenty years after the beginning of the decline in popular literacy. ${ }^{54}$ Rather, he opposes Sanderson's identification of the Industrial Revolution as one of the major factors that improved literacy rates, identifying a decline well before the Industrial Revolution is commonly held to have started. Laqueur has admitted the Industrial Revolution was not conducive to steady primary schooling for children, but nonetheless it seems to have changed the trends in literacy. ${ }^{55} \mathrm{He}$ suggested this change may have happened for several reasons: social opportunities were growing for jobs in which literacy was a distinct advantage and although basic literacy may have been declining, functional literacy may have actually risen. ${ }^{56}$

Sanderson responded to Laqueur's criticism in an article admitting the weakest part of his argument centers on social mobility and connecting literacy with certain occupation types. ${ }^{57}$ Sanderson had argued social mobility had declined, because there was less access to education, which for him was a contributing factor to social mobility. ${ }^{58}$ This problem stems from being unable to tell what kind of job a person had after marriage, whether they moved to the city for a different job, and whether their literacy skills changed. He also disagreed with the claim the Industrial Revolution could have had nothing to do with overall trends in literacy. Sanderson contested there were many small rises and falls in the levels of popular literacy, likely caused in part by the Industrial Revolution. ${ }^{59} \mathrm{He}$ also felt he had taken into consideration more factors than Laqueur. Laqueur relied solely on demographic factors, which do not give a very accurate idea of literacy rates because other factors such as school building and industrial change were also relevant. ${ }^{60}$ Demographics were probably the most important factor, but all three combined to produce low literacy rates twenty years after they came into effect. Finally, Sanderson believed he had been misrepresented in his discussion about low levels of literacy amongst Lancashire textile workers. ${ }^{61}$ There were likely very few textile workers

\footnotetext{
50 Ibid, 10.

51 Ibid, 11.

52 Thomas W. Laqueur, "Literacy and Social Mobility in the Industrial Revolution in England," Past and Present 64 (1974): 99.

53 Ibid.

54 Ibid.

55 Laqueur, "Literacy and Social Mobility," 101.

56 Ibid, 102-104.

57 Michael Sanderson, "Literacy and Social Mobility in the Industrial Revolution in England: A Rejoinder," Past and Present 64 (1974): 108.

58 Laqueur, "Literacy and Social Mobility," 105

${ }^{59}$ Sanderson, "Literacy and Social Mobility in the Industrial Revolution in England: A Rejoinder," 109.

${ }^{60}$ Ibid, 110.

${ }^{61}$ Sanderson, "Literacy and Social Mobility in the Industrial Revolution in England: A Rejoinder," 110-111.
} 
who were literate, simply because it was not in high demand for the jobs they did. However, Laqueur had accused him of saying that no Lancashire textile workers were literate.

Mitch suggested one of the factors involved in the rising literacy rates of the nineteenth century might have been the prestige associated with reading and writing. In the work force, for example, being literate was considered more respectable and employers perceived literate people to make better employees. ${ }^{62}$ Of course this varied between occupations, with managerial positions requiring more literacy than factory workers. People may have seen this prestige as motivation to learn to read and write, because it gave them better work options. ${ }^{63}$ In turn learning to read and write would have raised people's societal status. As such, those people's children were more likely to be literate and follow in their parents' footsteps. ${ }^{64}$ Finally, Mitch has asserted that more children were likely to go to school when the demand for children in the workforce declined in the second half of the nineteenth century. ${ }^{65}$ Falling birthrates and rising incomes made this more feasible. This is perhaps one of the reasons why literacy rates were relatively low in an overall sense between 1770 and 1850, the peak of the Industrial Revolution's need for child labour. He argued all of these factors including educational policy, the wealth and willingness of parents, and the prestige associated with reading and writing were important factors in raising literacy rates in the late eighteenth and nineteenth centuries.

Interestingly, Richard Altick explained the rise of the common reader in England as part of the struggle for democracy. He has attributed the increase in readership to people wanting to gain information, but also because reading became a form of leisure. ${ }^{66}$ The prevalence of the factory system and poor working conditions meant people needed an escape from their daily lives - one that was easily found in reading. Altick associated this trend with the struggle for democratic rights and equal access to information and representation. ${ }^{67}$ However, this trend was more prevalent in cities and amongst the middle class, where schools and access to reading materials were more common. ${ }^{68}$

\section{Literacy and Religion}

Another factor influencing education and literacy rates is the role of religion. Historians have focused on the role that Protestantism played in encouraging people to be literate. Protestantism encouraged people to read the Bible on their own. ${ }^{69}$ Previously, most people in Britain had relied on priests or other literate people to read the Bible aloud and interpret it for them, but Protestantism, especially Weslyanism, "preached the spiritual necessity of reading." 70 This was encouraged even though many people likely didn't understand what they were reading. As a result, there was a large increase in Sunday schools throughout the country between 1780 and $1820 .^{71}$ The Sunday schools focused mainly on teaching children to read and know the Scriptures. For many children this was the only primary schooling they received; they were unable to attend school regularly because of work reasons, or because their parents could not afford to send them to school more often. ${ }^{72}$ Children attended Sunday school, or affiliated night schools, once or twice a week for a couple of

\footnotetext{
62 Mitch, The Rise of Popular Literacy in Victorian England, 13.

${ }^{63}$ Ibid, 22.

64 Ibid, 80.

${ }^{65}$ Ibid, 158.

${ }^{66}$ Altick, The English Common Reader, 3-4.

${ }^{67}$ Ibid, 4.

${ }^{68}$ Ibid, 40-41.

${ }^{69}$ Ibid, $24-25$.

${ }^{70} \mathrm{Ibid}, 37$.

${ }^{71}$ Thomas Walter Laqueur, Religion and Respectability: Sunday Schools and Working Class Culture 1780-1850 (New Haven: Yale University Press, 1976), xi.

72 Ibid, 148-152.
} 
years on average. Different Sunday schools produced different results, but most children emerged from this basic education able to read adequately and possibly able to write and do arithmetic. The question that most historians have asked however, is whether these Sunday schools offered once or twice a week significantly increased rates of literacy. They also ask whether or not the religious motivation to become literate and to educate one's children affected the number of children attending schools and learning basic reading and writing skills.

Thomas Laqueur has written a seminal study on the impact of religion and Sunday schools on working class culture between 1780 and 1850. An interesting aspect of Sunday schools and education for the working classes is the contemporary debate about whether the poor should receive basic education they were unlikely to use in their jobs or daily lives. There was a clash of ideals between the Evangelicals, who wanted to educate the poor and rescue them morally, and the conservative backlash that believed the poor didn't need or deserve education. ${ }^{73}$ The idea was that too much education would give the people of the working class ideas above their station and they would no longer be content to work as servants or labourers. ${ }^{74}$ This argument was still prevalent in the 1780s and 1790s, though it was not nearly as widespread as it had been. However, the advent of the French Revolution reignited these fears in many because education now came with political overtones. ${ }^{75}$ The British elite could see what had happened in France and assumed that through education the masses would obtain tools for discontent and fanaticism. ${ }^{76}$ Others had more moderate views of educating the poor and working classes. Some thought that it wouldn't be harmful to society, but believed it served no real use and therefore was a waste of time and money. ${ }^{77}$

In 1785 the National Sunday School Society was formed and by 1797 there were approximately 69 000 children enrolled. ${ }^{78}$ Altick has argued Sunday schools did little to instill literacy into the country's children. Neither the children nor their families were particularly interested in the schools, which in any case only taught once a week. The schools were not particularly child-friendly because they didn't use material specifically for children. Many children most likely did not enjoy attending school and so may not have appreciated their reading and writing skills. Parents may not have been attracted to schools because it took away from the child's work around the house or as an income earner. The ideas from the French Revolution reinforced negative attitudes towards education for the upper classes as well. Alternately, the French Revolution may have increased interest in reading because people wanted to be informed and were starting to consider their rights more carefully. ${ }^{79}$ Thus, the Sunday school system was unwelcome to many of the upper class, because it was seen to disseminate radical ideas. Finally, the Protestant movement also made reading material more widely available. $^{80}$

However, the goal of Sunday schools was the instilment of spiritual and moral values. ${ }^{81}$ The education system, Sunday schools included, was not only designed to teach basic reading, writing and arithmetic, but also to educate children about their religion and how to behave properly. Most of the reading and writing children did was centered on the Bible. It was not until later on in the nineteenth century that books and exercises aimed specifically at children were developed. When

73 Ibid, 124-125.

${ }^{74}$ Laqueur, Religion and Respectability, 125.

75 Ibid, 126.

76 Ibid.

77 Ibid, 126-127.

78 Altick, The English Common Reader, 67.

${ }^{79}$ Altick, The English Common Reader, 72.

80 Ibid, 103.

${ }^{81}$ Mitch, The Rise of Popular Literacy in Victorian England, xx. 
children were taught to read and write it was mainly so they could adequately understand the Bible and their Sunday school lessons. On top of this, schooling was supposed to inculcate the sense of obedience and responsibility every good Protestant should have. ${ }^{82}$ Part of the Protestant ideal was for everyone to be God-fearing and do their part in society. Because this was the main goal, children sometimes left their years of primary education with only very basic reading skills and little or no writing skills. It has been argued that basic education was not even the true goal of some schools, rather it was to turn out productive and obedient workers who would be satisfied with their situation. Thus, although children may have attended school regularly, their skills may not have been well developed, because these skills weren't considered a priority.

Conversely, Michael Sanderson has stated the main role of Sunday schools during the Industrial Revolution was to stem falling literacy rates. ${ }^{83} \mathrm{He}$ sees them as a half-measure; meaning children involved in the factory system had some schooling, even though it was only once a week. As discussed above, Sanderson believed the Industrial Revolution produced a more illiterate society than before, because children were used as labourers instead of going to school. Sunday schools made up for this deficit in part, because a child could go to school once a week even if they were working in a factory. If it weren't for Sunday schools many working children during the Industrial Revolution might have never had any schooling, although in reality Sunday schools did not increase literacy rates noticeably.

\section{Gender and Literacy}

Interestingly, it seems that little work has been done on the differences between male and female literacy in this time period. Historians agree that literacy rates for women lagged significantly behind those of men until the beginning of the twentieth century, but when examining the general reading public of the late eighteenth and early nineteenth centuries, women and men tend to get lumped into a national mass of readers. This generalization may be have occurred, because rising literacy rates in women followed similar path as that of males, but about fifty years behind. Widespread access to education for women came significantly later than it did for men, though it had a similar affect on literacy rates as a whole.

Before the middle of the eighteenth century, there were few written works that women were supposed to be interested in reading. Most of the literature was what today is defined as non-fiction: philosophy, history and other "improvement" books. ${ }^{84}$ Women would have predominantly read books of sermons and the Scriptures. They did not have much to read in the way of novels or romances, and the "improvement" books were considered the domain of males. After the first novels came into publication an increased number of women became interested in reading for leisure. ${ }^{85}$

Mitch has noted that between 1754 and 1840, signature rates for grooms did not increase noticeably, while those for brides increased by $10 \%$ and by 1840 brides and grooms were equal: half could not sign their names on the marriage register. ${ }^{86}$ Thus, it seems as if for a period of close to one hundred years, women were beginning to catch up to their male counterparts, who seem to have stagnated.

Sanderson has claimed, while there was more pressure for women to be educated equally to men, there was still a fairly large discrepancy in literacy rates by 1851. This discrepancy stemmed from

\footnotetext{
82 Altick, The English Common Reader, 32.

${ }^{83}$ Sanderson, Education, Economic Change and Society in England 1780-1870, 6.

84 Altick, The English Common Reader, 45.

85 Ibid.

${ }^{86}$ Mitch, The Rise of Popular Literacy in Victorian England, 1.
} 
changes in demographics and societal norms: the age of marriage was rising and many women had no expectations at all of marriage. This in turn, meant that women were becoming less attached to parents and husbands and had to think more about earning a living on their own, bringing education to the forefront. ${ }^{87}$ Women were only $54 \%$ literate while men had made it up to $69 \%$, a fairly sizeable gap, even though women outnumbered men in the general population. A possible reason for this divide is the low quality of education in the first half of the nineteenth century. Girls had fewer opportunities in the job market, only a few of which required them to be literate. Upper class women could become governesses- though there was little formal training for this and the woman would have had to forfeit her status as a lady to take this kind of position. ${ }^{88}$ By taking a paid employment one fell out of the category of aristocrat. Lower class women had the option of becoming domestic servants or working a factory job and the educational curriculum associated with this was the same as that of males, with the addition of household management. Being literate would have been beneficial in some situations, but it was not necessary for many positions available to working class women. It wasn't until later in the century that more schools specifically for girls started to appear and that their education rates began to equal those of males.

Vincent gives us some numbers on brides and daughters in relation to literacy. It seems that, like males, literacy for brides was fairly directly related to occupation. However, for males, coming from a family background of industrial labour meant that they were significantly less likely to be literate, and the occupation of the father had much to do with it. On the other hand, for women, levels of illiteracy seem to be approximately the same, no matter what occupational background their family was from. ${ }^{89}$ This meant the increase in literacy across the country for females in the nineteenth century was much more uniform than it was for males. There seems to have been much less difference between occupations for women than there was for men. There was still some variation, but it seems that literacy rates for women were more equal in that sense than they were for men.

\section{Conclusion}

The many methodologies and angles that have been used to study literacy demonstrate it is a complex subject. Historians have been struggling to define what literacy means, how it can be measured, and what influences a person to become literate. Before being able to look at why a society's literacy rates increased though, a historian must seriously consider how they plan to define literacy for their study. There are many ways of defining it, including both reading and writing and the extent of understanding someone has of a text. Every historian of eighteenth and nineteenth century Britain has been forced to use marriage registers as the most conclusive form of evidence, even if there are many difficulties pertaining to the way they measure literacy. Marriage registers are the only reasonably complete source of evidence that we possess; other ways of measuring literacy are too inaccurate or dependent on too many different variables.

Once defining their standards for literacy, historians have chosen several different lenses through which to examine the extent of reading and writing. These include examining the education system, the effect of the Industrial Revolution, the role of religion and Sunday Schools, and some comparisons between genders. It is likely that all of these factors influenced literacy rates in eighteenth and nineteenth century Britain. Historians have debated the extent which each could have affected a regular working class person, though all acknowledge that it was a complex mix of societal, economic and political factors that contributed to rising literacy rates. As such, it seems best

\footnotetext{
87 Sanderson, Education, Economic Change and Society in England 1780-1870, 55.

88 Sanderson, Education, Economic Change and Society in England 1780-1870, 56.

89 Vincent, Literacy and Popular Culture, 101-103.
} 
to incorporate all of these factors when attempting to study literacy in a complete sense. Defining reasons for rises in literacy lay not in determining which factor contributed the most, but rather in investigating how they interacted to form the end product: mass literacy in Britain. 


\section{Bibliography}

Altick, Richard D. The English Common Reader: A Social History of the Mass Reading Public 1800-1900. Chicago: The University of Chicago Press, 1957.

Laqueur, Thomas Walter. Religion and Respectability: Sunday Schools and Working Class Culture 1780-1850. New Haven: Yale University Press, 1976.

Laqueur, Thomas W. "Literacy and Social Mobility in the Industrial Revolution in England". Past and Present 64 (1974): 96-107.

Mitch, David F. The Rise of Popular Literacy in Victorian England: The Influence of Private Choice and Public Policy. Philadelphia: University of Pennsylvania Press, 1992.

Payne, Jonathan. "Review Essay: Literacy and the Working Class". Labour History Review 67, no. 3 (2002): 365-373.

Sanderson, Michael. Education, Economic Change and Society in England 1780-1870. $2^{\text {nd }}$ ed. Cambridge: Cambridge University Press, 1995.

Sanderson, Michael. "Literacy and Social Mobility in the Industrial Revolution in England". Past and Present 56 (1972): 75-104.

Sanderson, Michael. "Literacy and Social Mobility in the Industrial Revolution in England: A Rejoinder". Past and Present 64. (1974): 108-112.

Schofield, R. S. "Dimensions of Illiteracy 1750-1850". Explorations in Economic History 10, no. 4 (1973): 437-454.

Stephens, W.B. ed. Studies in the History of Literacy: England and North America. Leeds: Museum of the History of Education, University of Leeds, 1983.

Stone, Lawrence. "Literacy and Education in England 1640-1900”. Past and Present 42 (1969): 69-139.

Vincent, David. Literacy and Popular Culture: England 1750-1914. Cambridge: Cambridge University Press, 1989.

West, E.G. "Resource Allocation and Growth in Early Nineteenth-Century British Education". Economic History Review 23, no. 1 (1970): 68-95. 